RESEARCH NOTE

\section{Absence of Tylodelphys barilochensis (Trematoda: Diplostomidae) - Induced Mortality in "Puyenes" Galaxias maculatus (Teleostomi: Galaxiidae) from Southern Argentina}

$J_{\text {Revenga }}{ }^{+}$, P Scheinert

Laboratorio de Ictiopatologia, Centro Regional Universitario Bariloche, Quintral 1250, 8400 Bariloche, Argentina

Key words: Galaxias maculatus (Teleostomi: Galaxiidae) - Tylodelphys barilochensis (Trematoda: Diplostomidae ) - parasite-induced host mortality

The "puyen", Galaxias maculatus, is a small, autochthonous fish (no longer than $10 \mathrm{~cm}$ in this region). This species is protected in the Nahuel Huapi National Park and Reserve. Information on its biology is available in RM McDowall (1968 Fish Res Bull 2: 1-84, 1972 J R Soc New Zel 2: 325-367), DA Pollard (1971 Aus J Mar Fresh Res 22: 91-123) and RA Ferriz (1987 Rev Mus Arg B Riv 5: 29-38).

Tylodelphys barilochensis is a digenetic trematode whose metacercaria stage parasitizes the "puyen" (EA Quaggiotto \& F Valverde 1992 Bol Chil Parasitol 47: 19-24), located in the host's brain cavity (P Scheinert et al. 1997 Rev Ictiol 5: 49-55).

T. barilochensis migration within the "puyen" body and its establishment in the brain and brain cavity causes damage such as hemorrhages and mild brain necrosis due to compression (Scheinert et al. loc. cit.).
RM Anderson and DM Gordon (1982 Parasitology 85: 373-398) introduced quantitative techniques for detecting signs of parasite-induced host mortality (PIHM) in fish populations. They accept that the probability of host death is a function of the number of parasites hosted and consider the decline in older fishes of both parasite abundance (mean number of parasites per fish) and degree of aggregation of parasite frequency distribution (measured as the variance to mean ratio) to be an evidence of such a mortality (though not conclusive).

This study applied these techniques to a "puyen" population in the Nahuel Huapi Lake.

Between January 20 and February 10, 1994, 579 "puyenes" G. maculatus were trapped at six sampling stations on the Nahuel Huapi Lake in the Nahuel Huapi National Park and Reserve (40 ${ }^{\circ}$ '$\left.41^{\circ} 35^{\prime} \mathrm{S}, 71^{\circ} 2^{\prime}-71^{\circ} 57^{\prime} \mathrm{W}\right)$. Traps were submerged at a depth not greater than $0.5 \mathrm{~m}$ for $1-5$ days ( $\mathrm{J}$ Revenga \& P Scheinert unpublished data). In the lab, the fishes were measured and dissected under stereomicroscope to determine sex (162 males, 154 females and 263 inmature) and identify and count helminth parasites. This paper reports parasite species, abundance and prevalence (percentage of infected fish) ranges, as reported by J Revenga and P Scheinert: T. barilochensis (27.6-124.4, 100\%), Acanthostomoides apophalliformis (0.6-0.9, 30$54 \%)$, Contracaecum sp. (0.3-0.9, 14-34\%) and Camallanus corderoi (0.1-0.2, 6-8\%).

Figure shows that both variance to mean ratio (a) and abundance (b) increase steadily with size (as age indicator) of fish, and therefore there are no signs of PIHM. It is therefore concluded that the injuries found during both experimental and natural infections by Scheinert et al. (loc. cit.), hemorrhages in different parts of the body, penetration of liver tissue, penetration of pericardial cavity and mild necrosis from compression of brain tissue, do not induce significant mortality in the "puyen" population studied. The fact that both fish and parasites are autochthonous, high parasite abundance and absence of PIHM suggest that the system has coevolved reciprocally, according to the mutualistic model reviewed by JC Holmes (1983 In DJ Futuyama \& M Slatkin (eds) Coevolution, Sinauer Associates Inc., Massachusetts).

\footnotetext{
This study was partially supported by grant No. B029 from Universidad Nacional del Comahue.

${ }^{+}$Corresponding author. Fax: +54-944-22111. E-mail: jrevenga@bariloche.com.ar Received 15 September 1998 Accepted 19 May 1999
} 

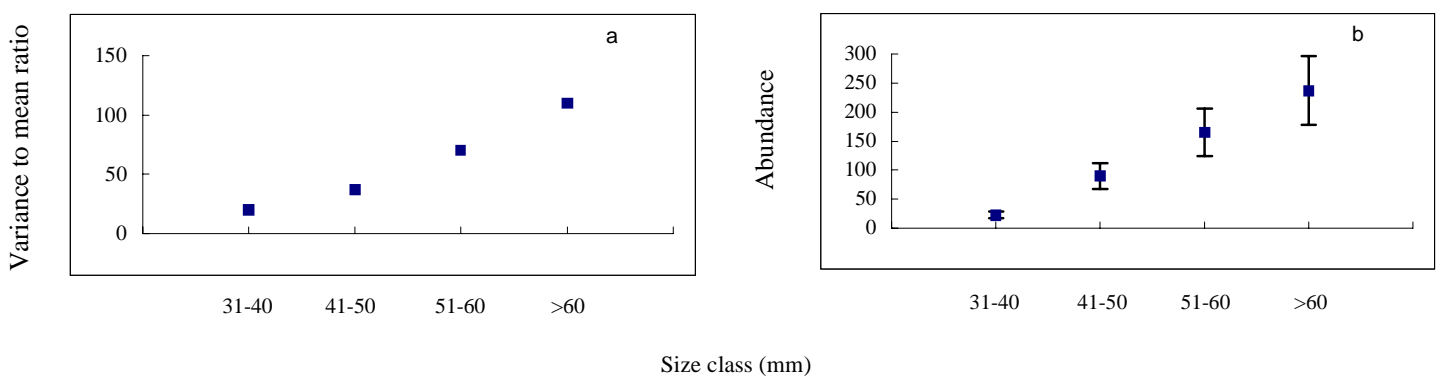

Variation of parameters for detecting parasite-induced host mortality according to host size (taken as age indicator) for Galaxias maculatus from the Nahuel Huapi Lake. a: variance to mean ratio; b: abundance ( \pm SD) 